\title{
Promoter CpG methylation of multiple genes in pituitary adenomas: Frequent involvement of Caspase-8
}

\author{
M. JOSEFA BELLO ${ }^{1}$, JOSE M. DE CAMPOS ${ }^{2}$, ALBERTO ISLA $^{3}$, CACILDA CASARTELLI $^{4}$ and JUAN A. REY ${ }^{1}$ \\ ${ }^{1}$ Unidad de Investigación, Laboratorio de Oncogenética Molecular y Epigenética del Cáncer, Hospital Universitario La Paz, \\ Paseo Castellana 261, 28046 Madrid; ${ }^{2}$ Departmento de Neurocirugía, Hospital del Rio Hortega, 47010 Valladolid; \\ ${ }^{3}$ Departmento de Neurocirugía, Hospital Universitario La Paz, 28046 Madrid, Spain; ${ }^{4}$ Laboratorio de \\ Oncogenetica, Departamento de Genetica, Facultade de Medicina de Ribeiräo Preto, \\ Universidade de Säo Paulo (FMR-USP), Ribeiräo Preto-Säo Paulo, Brazil
}

Received September 28, 2005; Accepted November 17, 2005

\begin{abstract}
The epigenetic changes in pituitary adenomas were identified by evaluating the methylation status of nine genes $\left(R B 1, p 14^{A R F}, p 16^{I N K 4 a}, p 73, T I M P-3, M G M T, D A P K, T H B S 1\right.$ and caspase-8) in a series of 35 tumours using methylationspecific PCR analysis plus sequencing. The series included non-functional adenomas $(n=23)$, prolactinomas $(n=6)$, prolactinoma plus thyroid-stimulating hormone adenoma $(n=1)$, growth hormone adenomas $(n=4)$, and adrenocorticotropic adenoma $(n=1)$. All of the tumours had methylation of at least one of these genes and $40 \%$ of samples (14 of 35) displayed concurrent methylation of at least three genes. The frequencies of aberrant methylation were: $20 \%$ for $R B 1,17 \%$ for $p 14^{A R F}, 34 \%$ for $p 16^{I N K 4 a}, 29 \%$ for $p 73,11 \%$ for TIMP-3, $23 \%$ for MGMT , $6 \%$ for DAPK, $43 \%$ for THBS1 and $54 \%$ for caspase-8. No aberrant methylation was observed in two non-malignant pituitary samples from healthy controls. Although some differences in the frequency of gene methylation between functional and non-functional adenomas were detected, these differences did not reach statistical significance. Our results suggest that promoter methylation is a frequent event in pituitary adenoma tumourigenesis, a process in which inactivation of apoptosis-related genes (DAPK, caspase-8) might play a key role.
\end{abstract}

\section{Introduction}

Pituitary tumours are mostly benign adenomas that grow slowly and frequently secrete hormone gene products, which

Correspondence to: Dr Juan A. Rey, Unidad de Investigacion, Lab. Oncogenetica Molecular y Epigenetica del Cancer, Hospital Universitario La Paz, Paseo Castellana 261, 28046 Madrid, Spain E-mail: jarey.hulp@salud.madrid.org

Key words: pituitary adenomas, $\mathrm{CpG}$ island, promoter hypermethylation, caspase- 8 can lead to disturbed endocrine functions. Aggressively growing adenomas, showing signs of local invasion, are, however, relatively common $(1,2)$. These neoplasms represent approximately $10 \%$ of brain tumours, and are the most common adult intracranial neoplasm.

There is some information on the genetic abnormalities leading to pituitary tumour formation. Cytogenetic and CGH studies have identified consistent gains of chromosomes $\mathrm{X}$, $19,12,9,7$ and 3 , and losses of chromosomes 10, 11, 13, 14, 19 and 22 , thus suggesting that tumour-related genes located in these genomic regions may play a role in pituitary tumorigenesis (3-7). Point mutations in the GS protein gene (leading to constitutive activation of the cAMP pathway) (8), or MEN1 gene (9), as well as high pituitary tumour transforming (PTT) gene expression (10), have been associated with pituitary tumorigenesis and invasiveness. Early studies on the cell-cycle regulators, $R B 1 / p 16^{I N K 4 a}$, demonstrated non-random abnormalities of these genes parallel to the loss of their corresponding protein products. Simpson et al (11) demonstrated the absence of pRB 1 in $27 \%$ of somatotrophinomas and $4 \%$ of nonfunctional tumours, but this finding was not associated with mutations at the $R B 1$ locus. Similarly, early studies of $p 16^{I N K 4 a}$ in pituitary tumours showed loss of the protein without evident mutations (detected by SSCP) and only a small proportion of adenomas $(\sim 12 \%)$ displayed homozygous deletions of this gene $(12,13)$. These data thus demonstrated that the loss of function by these cell-cycle regulator genes is a non-random event in pituitary tumorigenesis, and suggested that genesilencing mechanisms other than mutation or deletion might be responsible for their inactivation.

Methylation of gene regulatory elements is an epigenetic change that is an alternative mechanism to genetic alteration for gene inactivation. $\mathrm{CpG}$ islands are $0.5-2.0 \mathrm{~Kb}$ regions that are rich in cytosine-guanine dinucleotides and are present in the 5 ' region of approximately half of all human genes. Methylation of the $\mathrm{CpG}$ island located within a promoter element is generally associated with delayed replication and inhibition of transcription initiation (14), thus contributing to the pathogenesis and progression of malignant neoplasms. Examples of this process have been reported in a wide range of tumour types and cancer-related genes (15) and some 
information is available on pituitary tumours (reviewed in ref. 16). A study by Simpson et al (17) detected aberrant $R B 1$ promoter methylation in six of ten cases that failed to express pRB1, and three additional tumours presented deletions within the protein-binding pocket domain. In contrast, most adenomas and all normal pituitary tissues that expressed pRB1 displayed unmethylated $R B 1$ promoter (17). In addition to the welldocumented gene deletion, aberrant promoter methylation has also been described as an alternative mechanism to silencing of the $p 16^{I N K 4 a}$ gene (18-21). Some differences with respect to the frequency of $p 16^{I N K 4 a}$ hypermethylation in distinct pituitary tumour subtypes were found; the common data of these reports indicate that non-functional tumours are sites of epigenetic change, and that methylation of this gene is infrequent in somatotrophinomas (18-21).

Additional reports recently demonstrated that the loss of $D A P K$ (death associated protein kinase) expression, frequently parallel to aberrant hypermethylation or homozygous deletion, was associated with invasive pituitary tumours (22), whereas high methylation frequencies of the RASSF $1 A$ promoter were identified in the most aggressive adenomas (23).

All of these findings thus suggest that inappropriate methylation is a frequent event in pituitary tumorigenesis and may affect multiple genes in this neoplasm. In the present study, we determined the frequency of methylation of nine genes in a series of 35 pituitary adenomas, and controls consisting of two normal pituitary tissue samples, using polymerase chain reaction (PCR)-based techniques involving sodium bisulphite modification of DNA (MSP) plus sequencing.

\section{Materials and methods}

Tissue specimens and DNA extraction. Thirty-five sporadic human pituitary adenomas with matched blood samples were obtained from patients who had undergone hypophysectomy. The age range at diagnosis was from 20 to 74 years (mean age 45.68 years). Eighteen patients were male and seventeen were female. Clinical and immunohistochemical studies allowed tumour classification as follows: non-functional (NF) adenomas, 23 cases; functional (F) including prolactinomas, six cases; prolactinoma plus thyroid-stimulating hormone adenoma, one case; growth hormone adenomas, four cases; and adrenocorticotropic adenoma, one case. In addition to tumours, two histologically normal (postmortem) pituitary samples were also studied. Genomic DNA was extracted from frozen samples as described previously (24).

MSP and direct sequencing. We analysed the status of nine genes frequently showing promoter methylation in other neoplasms. The genes studied were $R B 1, p 14^{A R F}, p 16^{I N K 4 a}$, $p 73, T I M P-3$ (the tissue inhibition of metalloproteinase 3 gene) $M G M T$ ( $\mathrm{O}^{6}$-methylguanine DNA-methyl transferase), DAPK, THBS1 (thrombospondin-1) and caspase-8 (cyteine-aspartic acid protease 8). These genes were chosen for study on the basis of their critical cancer-related function, since they are frequently hypermethylated and silenced in other neoplasms, as well as being located in genomic regions known to be involved in chromosome deletions in pituitary adenomas. Bisulphite modification of genomic DNA was performed as reported (25). Briefly, $2 \mu \mathrm{g}$ of genomic DNA was denatured with $2 \mathrm{M}$ of $\mathrm{NaOH}$ and modified with sodium bisulphite treatment. After purification with the DNA clean-up kit (Promega, Madison, WI), the DNA was treated with $\mathrm{NaOH}$, precipitated with ethanol, and resuspended in water. PCR was conducted with primers specific for either the methylated or the unmethylated alleles in standard conditions with variable annealing temperatures $\left(55-66^{\circ} \mathrm{C}\right)$, using the Biotools DNA polymerase kit (Madrid, Spain). We used the primer sets described previously (26). Water was substituted for DNA as a negative control, and as a positive control for the methylated alleles we treated DNA (from healthy volunteers' lymphocytes) with Sss 1 methyl-transferase (New England Biolabs, Beverly, MA, USA) and then subjected it to bisulphite treatment. PCR products were loaded onto $6 \%$ polyacrylamide gels or $2-3 \%$ agarose gels, stained with ethidium bromide and visualised under UV. Samples giving signals approximately equivalent to the positive control were designated as methylated. To verify the identity of PCR products, they were purified and sequenced using the ABI PRISM Big-Dye Terminator cycle sequencing ready reaction kit (Applied Biosystems, Foster City, CA, USA) on AB model 3100 or 377 DNA sequencers. A given tumour, identified by MSP, was confirmed as methylated whenever at least $51 \%$ of the studied CpG sites were methylated.

\section{Results}

The results of the MSP analysis for the nine loci are shown in Table I. Nearly all of the tumours showing methylation by MSP, showed complete methylation at almost every individual $\mathrm{CpG}$ site analysed in the corresponding gene promoter. Partially methylated promoters (with $<50 \%$ methylated $\mathrm{GpG}$ sites) constituted $<10 \%$ of the methylated genes identified by MSP, and were considered as non-methylated for the study. All 35 samples showed methylation in at least one of these loci, and 14 adenomas (40\%) displayed concurrent methylation of three or more loci. Methylation of only one gene was observed in 11 adenomas corresponding to eight NF and three functional (F) tumours. Overall methylation values of $\geq 15 \%$ were obtained for seven genes: RB1 (20\%), p14 ${ }^{A R F}$ (17\%), p16 INK4a $(34 \%), p 73$ (29\%), MGMT (23\%), THBS1 $(43 \%)$ and caspase $8(54 \%)$. The remaining two genes (TIMP-3 and $D A P K$ ) presented methylation frequencies of $<15 \%$. Both samples of normal pituitary tissue displayed the unmethylated alleles of all nine genes analysed; representative examples of the MSP analysis are shown in Fig. 1.

We used the methylation index (MI) defined as the number of methylated loci/the number of tested loci, to determine the frequency of methylation of multiple genes in a given sample or tumour group. The MI ranged from 0.11 to 0.55 , with an overall mean of 0.260 . As shown in Table II, the overall MI value was slightly higher for NF adenomas (0.267) than F tumours $(0.247)$, but these differences did not reach statistical significance. Similar MI values were also detected between the distinct $\mathrm{F}$ adenoma groups (except the ACTH group that included a single case): PRL, 0.267; GH adenomas, 0.24. The frequency of aberrant gene methylation in NF versus $\mathrm{F}$ tumours was similar for MGMT, DAPK, THBS1 and caspase 8. In contrast, $R B 1, p 16^{I N K 4 a}$ and TIMP-3 were more frequently methylated in the NF group of adenomas; $p 14^{A R F}$ and $p 73$ displayed a higher frequency of methylation in the $\mathrm{F}$ tumours. 
Table I. Summary of clinicopathological data and methylation of all nine genes in pituitary adenomas.

\begin{tabular}{|c|c|c|c|c|c|c|c|c|c|c|c|c|}
\hline Sample & Sex/Age & Imm-Chem & $R B 1$ & $p 14^{A R F}$ & $p 16 I^{N K 4 a}$ & TP73 & TIMP3 & $M G M T$ & $D A P K$ & THBS1 & Caspase 8 & MI \\
\hline PA-1 & $\mathrm{F} / 67$ & NF & + & - & - & + & - & - & - & + & + & 0.44 \\
\hline PA-2 & $\mathrm{M} / 45$ & NF & - & - & - & + & - & - & - & + & - & 0.22 \\
\hline PA-3 & $\mathrm{F} / 30$ & NF & - & - & - & - & - & - & - & + & - & 0.11 \\
\hline PA-4 & $\mathrm{M} / 54$ & NF & - & - & - & - & - & - & - & + & - & 0.11 \\
\hline PA-6 & $\mathrm{M} / 74$ & NF & + & - & - & - & - & - & - & - & - & 0.11 \\
\hline PA-7 & $\mathrm{M} / 72$ & $\mathrm{NF}$ & - & - & - & - & - & - & - & - & + & 0.11 \\
\hline PA-8 & $\mathrm{M} / 55$ & NF & - & - & - & - & - & - & - & - & + & 0.11 \\
\hline PA-9 & $\mathrm{M} / 46$ & NF & - & - & - & - & - & + & - & - & + & 0.22 \\
\hline PA-11 & $\mathrm{F} / 45$ & $\mathrm{NF}$ & - & + & + & - & - & + & - & + & + & 0.55 \\
\hline PA-12 & $\mathrm{M} / 39$ & $\mathrm{NF}$ & + & + & - & + & - & - & - & - & + & 0.44 \\
\hline PA-17 & $\mathrm{M} / 74$ & $\mathrm{NF}$ & - & - & + & - & + & + & - & + & + & 0.55 \\
\hline PA-18 & $\mathrm{M} / 56$ & $\mathrm{NF}$ & + & - & - & + & - & + & - & - & - & 0.33 \\
\hline PA-19 & M/ 57 & $\mathrm{NF}$ & - & + & + & - & - & + & - & + & + & 0.55 \\
\hline PA-21 & $\mathrm{M} / 45$ & $\mathrm{NF}$ & - & - & - & + & + & - & - & - & + & 0.33 \\
\hline PA-22 & $\mathrm{F} / 56$ & NF & - & - & + & - & - & - & - & + & + & 0.33 \\
\hline PA-23 & $\mathrm{F} / 62$ & NF & - & - & - & - & - & - & - & - & + & 0.11 \\
\hline PA-25 & $\mathrm{F} / 32$ & $\mathrm{NF}$ & - & - & + & - & - & - & - & - & - & 0.11 \\
\hline PA-26 & $\mathrm{M} / 22$ & NF & - & - & + & - & - & - & - & - & - & 0.11 \\
\hline PA-29 & $\mathrm{F} / 46$ & NF & - & - & + & + & + & - & - & - & - & 0.33 \\
\hline PA-30 & $\mathrm{F} / 45$ & $\mathrm{NF}$ & + & - & + & - & - & - & - & - & + & 0.33 \\
\hline PA-32 & $\mathrm{F} / 48$ & $\mathrm{NF}$ & + & - & - & - & - & - & - & + & - & 0.22 \\
\hline PA-33 & $\mathrm{F} / 44$ & NF & - & - & + & - & - & - & - & - & + & 0.22 \\
\hline PA-35 & $\mathrm{F} / 46$ & $\mathrm{NF}$ & - & - & + & - & - & - & + & - & - & 0.22 \\
\hline \multicolumn{3}{|c|}{ Total non-functional adenomas } & $6 / 23$ & $3 / 23$ & $10 / 23$ & $6 / 23$ & $3 / 23$ & $5 / 23$ & $1 / 23$ & $9 / 23$ & $13 / 23$ & 0.24 \\
\hline & & $\%$ & 26 & 13 & 43 & 26 & 13 & 22 & 4 & 39 & 57 & \\
\hline PA-5 & $\mathrm{M} / 66$ & PRL & - & - & - & - & - & - & - & + & - & 0.11 \\
\hline PA-13 & $\mathrm{F} / 20$ & PRL & - & + & - & - & - & - & - & + & - & 0.22 \\
\hline PA-14 & $\mathrm{F} / 21$ & PRL & - & + & - & + & - & - & - & + & + & 0.44 \\
\hline PA-15 & $\mathrm{M} / 37$ & PRL & - & - & + & + & - & + & - & - & + & 0.44 \\
\hline PA-24 & $\mathrm{F} / 21$ & PRL & + & - & - & + & - & - & - & - & - & 0.22 \\
\hline PA-34 & $\mathrm{F} / 24$ & PRL & - & - & + & - & - & - & - & - & + & 0.22 \\
\hline \multirow[t]{3}{*}{ PA-20 } & $\mathrm{F} / 25$ & $\mathrm{PRL}+\mathrm{TSH}$ & - & - & - & - & + & - & - & - & + & 0.22 \\
\hline & & Total PRL & $1 / 7$ & $2 / 7$ & $2 / 7$ & $3 / 7$ & $1 / 7$ & $1 / 7$ & $0 / 7$ & $3 / 7$ & $4 / 7$ & 0.26 \\
\hline & & $\%$ & 14 & 29 & 29 & 43 & 14 & 14 & 0 & 43 & 57 & \\
\hline PA-10 & $\mathrm{M} / 44$ & $\mathrm{GH}$ & - & - & - & + & - & - & - & + & + & 0.33 \\
\hline PA-27 & $\mathrm{F} / 44$ & $\mathrm{GH}$ & - & - & - & - & - & - & + & - & - & 0.11 \\
\hline PA-28 & $\mathrm{M} / 45$ & $\mathrm{GH}$ & - & - & - & - & - & + & - & - & + & 0.22 \\
\hline \multirow[t]{3}{*}{ PA-31 } & $\mathrm{M} / 46$ & $\mathrm{GH}$ & - & + & - & - & - & + & - & + & - & 0.33 \\
\hline & & Total GH & $0 / 4$ & $1 / 4$ & $0 / 4$ & $1 / 4$ & $0 / 4$ & $2 / 4$ & $1 / 4$ & $2 / 4$ & $2 / 4$ & 0.24 \\
\hline & & $\%$ & 0 & 25 & 0 & 25 & 0 & 50 & 25 & 50 & 50 & \\
\hline
\end{tabular}

Total functional adenomas

$$
\%
$$

Total series 

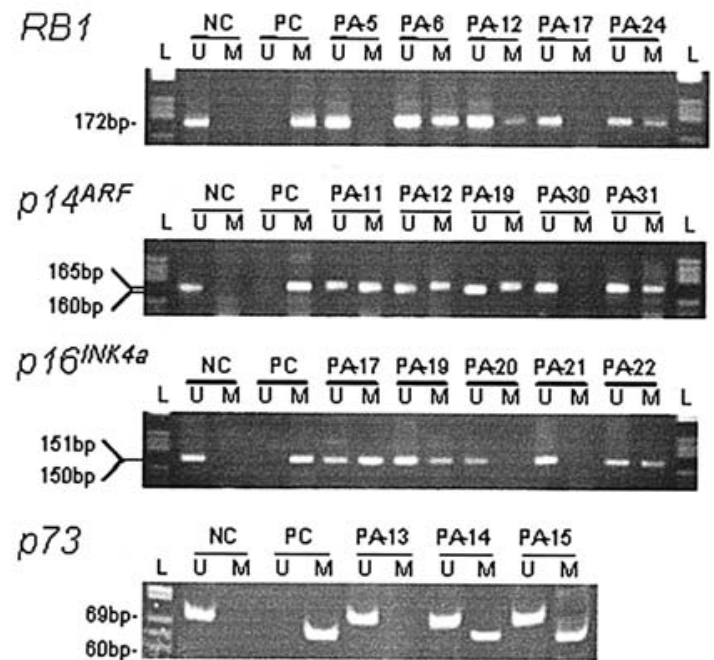

TIMP-3 PA17 PA20 PA21 PA22 PA23 NC PC

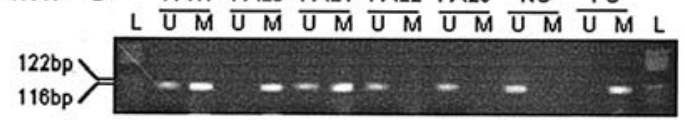

MGMT PC NC PA9 PA10 PA11 PA15 PA16
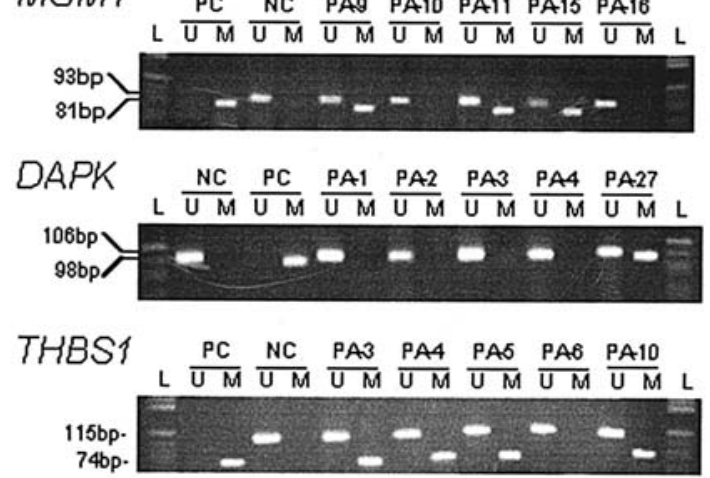

Caspase-8 NC PC PA9 PA10 PA11 PA12 PA13

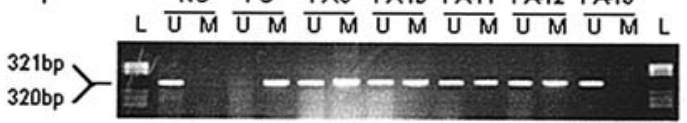

Figure 1. Methylation analysis of pituitary adenomas by MSP. The gene studied is given at the left. Lane $\mathrm{U}$, amplified product with primers recognising unmethylated sequence; Lane M, amplified product with primers recognising methylated sequence. PC, positive control for methylation. NC, negative control for methylation. The PCR product sizes of all genes are shown to the left. L, ladder.

However, these differences did not reach statistical significance $\left(\chi^{2}\right.$ and Fisher's exact tests).

There was no significant association between overall MI and sex/age distribution, although the tumours arising in male patients, or in patients under 46 years of age presented higher MI values.

\section{Discussion}

This study presents the first analysis of the methylation profile of nine tumour-related genes in pituitary adenomas. The results demonstrate that this epigenetic change is a relatively frequent event in this neoplasm since at least one gene was methylated in all of the analysed samples. Although hypermethylation varied according to the gene, there were significant MI values per tumour, ranging from 0.11 to 0.55
Table II. Summary of the overall MI findings related to immunohistochemical and clinicopathological data.

\begin{tabular}{lcc}
\hline Characteristics & $\begin{array}{c}\text { No. of cases } \\
\text { examined }\end{array}$ & MI value \\
\hline Total tumours & 35 & $0.260 \pm 0.141$ \\
Tumours arising in female patients & 17 & $0.258 \pm 0.128$ \\
Tumours arising in male patients & 18 & $0.267 \pm 0.156$ \\
Tumours arising in & & \\
patients <46 years & 18 & $0.268 \pm 0.131$ \\
Tumours arising in & & \\
patients $>46$ years & 17 & $0.252 \pm 0.154$ \\
Non-functional tumours & 23 & $0.267 \pm 0.154$ \\
Functional tumours & 12 & $0.247 \pm 0.116$ \\
Prolactinomas & 7 & $0.267 \pm 0.124$ \\
GH adenomas & 4 & $0.24 \pm 0.09$ \\
ACTH adenomas & 1 & 0.11 \\
\hline
\end{tabular}

(mean 0.26). We also identified non-random frequencies of aberrant promoter methylation in most analysed genes, but only seven of them $\left(R B 1, p 14^{A R F}, p 16^{I N K 4 a}, p 73\right.$, MGMT, THBS1 and caspase 8) were methylated in at least $15 \%$ of the analysed samples.

In 21 adenomas for which enough DNA was available, we performed mutational analysis of $p 16^{I N K 4 a}$ (exons 1, 2 and 3) and $R B I$ (exons 20-24 and the essential promoter region) (unpublished data). No mutations or deletions were observed in $R B 1$. A polymorphic variant at the 3'UTR of $p 16^{1 N K 4 a}$ was identified in three tumours (PA-5, PA-7 and PA-21) and a homozygous deletion of this gene (as determined by multiplex PCR) could be identified in two cases (PA-16 and PA-18). Accordingly, these data confirm that mutation or homozygous deletions of $R B 1$ pathway genes would be a rare event in pituitary adenomas $(12,13,17,20,21,27)$. In agreement with previous studies suggesting that $R B 1$ pathway gene expression may be altered by epigenetic changes in most pituitary adenomas $(16-21,27)$, we identified aberrant promoter methylation of either $R B 1$ or $p 16^{I N K 4 a}$ in $51 \%$ of the cases in this series, primarily the non-functional adenomas and prolactinomas. However, no GH adenoma in our series presented these epigenetic changes. Previous studies, primarily focusing on p16 ${ }^{I N K 4 a}$ aberrant methylation, showed controversial findings in these $\mathrm{GH}$ adenomas since the reported frequency of hypermethylated alleles varied from $8-9.5 \%(18,20)$ to $42.9 \%$ or $81.8 \%(21,29)$.

In addition to $p 16^{I N K 4 a}$, the same locus at $9 \mathrm{p} 21$ encodes $p 14^{A R F}$, as a result of alternative spliced RNAs. The p14 protein binds to mdm2 and stabilises both TP53 and mdm2 (30) thus forming a gene pathway that participates in regulation of gene transcription, induction of G1/S arrest and apoptosis promotion. Mutations of TP53 may be present in a subset of pituitary adenomas and a role for these genetic alterations in the acquisition of malignant phenotypes has been proposed (reviewed in ref. 31). The epigenetic inactivation of $p 14^{A R F}$ due to aberrant promoter methylation that we detected in 
$17 \%$ of samples in our series may represent an alternative mechanism for inactivating TP53/mdm $2 / p 14^{A R F}$ gene function in pituitary adenoma development.

Our results also showed that $p 73, T I M P-3, M G M T$ and THBS1 were methylated at significant rates in both functional and non-functional adenomas. Expression silencing by aberrant promoter methylation of these genes has been well-documented in a variety of neoplasms (15). These genes play key roles (angiogenesis or invasion inhibition, DNA repair) in tumour development; accordingly, their epigenetic alteration may represent a mechanism that could disrupt key cellular functions and contribute to pituitary adenoma development. These biological implications, however, need to be studied further in larger tumour series.

Apoptosis-related genes, such as DAPK and PTAG (pituitary tumour associated gene), have recently been identified as participating in the formation of these tumour types $(22,32)$. The loss of DAPK expression in these studies was significantly associated with invasive pituitary tumours (59\% of cases versus $7 \%$ in non-invasive cases). Aberrant promoter methylation and, less frequently, homozygous deletion have been identified as the main mechanisms responsible for $D A P K$ silencing (22). Two of the adenomas that we studied $(6 \%)$ present aberrant promoter methylation of this gene; this low frequency may be due to the fact that all of the cases in our series were non-invasive. However, it should not be forgotten that Simpson et al (22) suggested that these 'non-invasive' adenomas with $D A P K$ silencing may be predisposed toward an invasive or metastatic phenotype. We detected high rates of aberrant methylation (54\%) affecting another apoptosis-related gene: caspase-8. Binding of TNFrelated apoptosis-inducing ligands (TRAIL) to death receptor 4 and 5 allows caspase- 8 to bind to the receptor, leading to the proteolytic activation that initiates a cascade of caspases causing apoptosis (33). Silencing of caspase- 8 due to aberrant $\mathrm{CpG}$ island methylation has previously been documented in medulloblastomas and neuroblastomas (26,34-36). Those tumours that do not express caspase- 8 may avoid apoptosis and acquire a more aggressive and therapy-resistant tumour phenotype (35). Demethylation with 5-aza-2' deoxycytidine has been demonstrated to restore caspase- 8 mRNA expression and, thus, TRAIL sensitivity in medulloblastoma-derived cell lines, suggesting that caspase- 8 could be a target for chemotherapy with inhibitors of DNA methylation (35). Therefore, in addition to the previously well-established epigenetic inactivation of cell-cycle control genes, apoptosis-related genes are frequently silenced through aberrant promoter methylation in pituitary tumours and may represent targets for new therapeutic options on the basis of their epigenetic status.

\section{Acknowledgements}

We are indebted to Dr J.L. Sarasa and to Dr M. Gutierrez for their histological diagnoses of tumours. This work was supported by FIS, Ministerio de Sandad, Grant no: 03/0235.

\section{References}

1. Shimon I and Melmed S: Genetic basis of endocrine disease: pituitary tumor pathogenesis. J Clin Endocr Metab 82: 1675-1681, 1997.
2. Assa SL and Ezzat SZ: The cytogenesis and pathogenesis of pituitary adenomas. Endocr Rev 19: 798-827, 1998.

3. Finelli P, Giardino D, Rizzi N, Buiatiotis S, Virduci T, Franzin A, Losa M and Larizza L: Non-random trisomies of chromosomes 5, 8 and 12 in the prolactinoma sub-type of pituitary adenomas: conventional cytogenetics and interphase FISH study. Int $\mathbf{J}$ Cancer 86: 344-350, 2000.

4. Bello MJ, de Campos JM, Kusak ME, Vaquero J, Sarasa JL and Rey JA: Chromosomal abnormalities in pituitary adenomas. Cancer Genet Cytogenet 124: 76-79, 2001.

5. Fan X, Paetau A, Aalto Y, Valimaki M, Sane T, Porenen A, Castresana JS and Knuutila S: Gain of chromosome 3 and loss of $13 q$ are frequent alterations in pituitary adenomas. Cancer Genet Cytogenet 128: 97-103, 2001.

6. Trautmann K, Thakker RV, Ellison DW, Ibrahim A, Lees PD, Harding B, Fischer C, Popp S, Bartram CR and Jauch A: Chromosomal aberrations in sporadic pituitary tumors. Int $\mathbf{J}$ Cancer 91: 809-814, 2001.

7. Simpson DJ, Bicknell EJ, Buch HN, Cutty SJ, Clayton RN and Farrel WE: Genome-wide amplification and allelotyping of sporadic adenomas identify novel regions of genetic loss. Genes Chromosomes Cancer 37: 225-236, 2003.

8. Landis CA, Masters SB, Spada A, Pace AM, Bourne HR and Valar L: GTPase inhibiting mutations activate the alpha chain of Gs and stimulate adenylate cyclase in human pituitary tumors. Nature 340: 566-568, 1989

9. Zhuang Z, Ezzat SZ, Vortmeyer AO, Weil R, Oldfield EH, Park W-S, Pack S, Huang S, Agarwal SK, Guru SC, Manickam P, Debelenko LV, Kester MB, Olufemi S-E, Heppener C, Crabtree JS, Burns AL, Spiegel AM, Marx SJ, Chandrasekharappa SC, Collins FS, Emmert-Buck MR, Liotta IA, Asa SL and Lubensky IA: Mutations of the MEN1 tumor suppressor gene in pituitary tumors. Cancer Res 57: 5446-5451, 1997.

10. Zhang X, Horwitz GA, Heaney AP, Nakamura M, Prezant TR, Bronstein MD and Melemd S: Pituitary tumor transforming gene (PTTG) expression in pituitary adenomas. J Clin Endocrinol Metab 84: 761-767, 1999.

11. Simpson DJ, Magnay J, Bicknell JE, Barkan AL, McNicol AM, Clayton RN and Farrell WE: Chromosome 13q deletion mapping in pituitary tumors: infrequent loss of the retinoblastoma susceptibility gene $(R B 1)$ locus despite of $R B 1$ protein product in somatotrophinomas. Cancer Res 59: 1562-1566, 1999.

12. Woloschak M, Yu A, Xiao J and Post KD: Frequent loss of $P 16^{I N K 4 a}$ gene product in human pituitary tumors. Cancer Res 56: 2493-2496, 1996

13. Farrell WE, Simpson DJ, Bicknell JE, Talbot AJ, Bates AS and Clayton RN: Chromosome 9p deletions in invasive and noninvasive nonfunctional pituitary adenomas: the deleted region involves markers outside of the MTS1 and MTS2 genes. Cancer Res 57: 2703-2709, 1997.

14. Baylin SB, Herman JG, Graff JR, Vertino PM and Issa JP: Alterations in DNA methylation: a fundamental aspect of neoplasia. Adv Cancer Res 72: 141-196, 1998.

15. Esteller M, Corn PG, Baylin SB and Herman JG: A gene hypermethylation profile of human cancer. Cancer Res 61: 3225-3229, 2001 .

16. Farrell WE and Clayton RN: Epigenetic change in pituitary tumorigenesis. Endocr-Relat Cancer 10: 323-330, 2003.

17. Simpson DJ, Hibberts NA, McNicol AM, Clayton RN and Farrell WF: Loss of pRb expression in pituitary adenomas is associated with methylation of the $R B 1 \mathrm{CpG}$ island. Cancer Res 60: 1211-1216, 2000.

18. Simpson DJ, Bicnell JE, McNicol AM, Clayton RN and Farrell WE: Hypermethylation of the p16/CDKN2A/MTS1 gene and loss of protein expression is associated with non-functional pituitary adenomas but not somatotrophinomas. Genes Chromosomes Cancer 24: 328-336, 1999.

19. Ruebel KH, Jin L, Zhang S, Scheitauer BW and Lloyd RV: Inactivation of the p16 gene in human pituitary non-functional tumors by hypermethylation is more common in null cell adenomas. Endocr Pathol 12: 281-289, 2001.

20. Seemann N, Kuhn D, Wrocklage C, Keyvani K, Hackl W, Buchfelder M, Fahlbusch R and Paulus W: CDKN2A/p16 inactivation is related to pituitary adenoma type and size. $\mathrm{J}$ Pathol 193: 491-497, 2001.

21. Ogino A, Yoshino A, Katayama Y, Watanabe T, Ota T, Komine C, Yokoyama T and Fukushima T: The p15INK4b/ p16INK4a/RB1 pathway is frequently deregulated in human pituitary adenomas. J Neuropathol Exp Neurol 64: 398-403, 2005 . 
22. Simpson DJ, Clayton RN and Farrell WE: Preferential loss of Death Associated Protein Kinase expression in invasive pituitary tumours is associated with either $\mathrm{CpG}$ island methylation or homozygous deletion. Oncogene 21: 1217-1224, 2002.

23. Qian ZR, Sano T, Yoshimoto K, Yamada S, Ishizuka A, Mizusawa N, Horiguchi H, Hirokawa M and Asa SL: Inactivation of RASSF1A tumour-suppressor gene by aberrant promoter hypermethylation in human pituitary adenomas. Lab Invest 85: 464-473, 2005.

24. Rey JA, Bello MJ, Jimenez-Lara A, Vaquero J, Kusak ME, de Campos JM, Sarasa JL and Pestaña A: Loss of heterozygosity for distal markers on $22 \mathrm{q}$ in human gliomas. Int J Cancer 51 : 703-706, 1992.

25. Herman JG, Graff JR, Myohannen S, Nelkin BD and Baylin SB: Methylation specific PCR: a novel PCR assay for methylation status of CpG islands. Proc Natl Acad Sci USA 93: 9821-9826, 1996.

26. Gonzalez-Gomez P, Bello MJ, Lomas J, Arjona D, Alonso ME, Amiñoso C, Lopez-Marin I, Anselmo NP, Sarasa JL, Gutierrez M, Casartelli C and Rey JA: Aberrant methylation of multiple genes in neuroblastic tumours: relationship with MYCN amplification and allelic status at 1p. Eur J Cancer 39: 1478-1485, 2003.

27. Yoshimoto K, Tanaka C, Yanmada S, Kimura T, Iwahana H, Sano $\mathrm{T}$ and Itakura M: Infrequent mutations of p16INK4A and p15INK4B genes in human pituitary tumors. Eur J Endocrinol 136: 74-80, 1997.

28. Woloschak M, Yu A and Post KD: Frequent inactivation of the p16 gene in human pituitary tumors by gene methylation. Mol Carcinog 19: 221-224, 1997.
29. Jaffrain-Rea ML, Ferretti F, Toniato E, Cannita K, Santoro A, di Stefano D, Ricevuto E, Maroder M, Tamburrano G, Cantore G, Gulino A and Martinotti S: p16(INK4a, MTS-1) gene polymorphism and methylation status in human pituitary tumours. Clin Endocrinol 51: 317-325, 1999.

30. Kamijo T, Weber JD, Zambetti G, Zindy F, Roussel MF and Sher CJ: Functional and physical interactions of the ARF tumor suppressor with p53 and Mdm2. Proc Natl Acad Sci USA 95: 8292-8297, 1998.

31. Tada M, Kobayashi H and Moriuchi T: Molecular basis of pituitary oncogenesis. J Neuro-Oncol 45: 83-96, 1999.

32. Bahar A, Simpson DJ, Cutty SJ, Bicknell JE, Hoban PR, Holley S, Mourtada-Maarabouni M, Williams GT, Clayton RN and Farrell WE: Isolation and characterization of a novel pituitary tumor apoptosis gene. Mol Endocrinol 18: 1827-1839, 2004.

33. Bodmer JL, Holler N, Reynard S, Vinciguerra P, Schneider P, Juo P, Blenis J and Tschopp J: TRAIL receptor-2 signals apoptosis through FADD and caspase-8. Nat Cell Biol 2: 241-243, 2000.

34. Teitz T, Wei T, Valentine MB, Vanin EF, Grenet J, Valentine VA, Behm FG, Look AT, Lahti JM and Kidd VJ: Caspase 8 is deleted or silenced preferentially in childhood neuroblastomas with amplification of MYCN. Nat Med 6: 529-535, 2000.

35. Pingoud-Meier C, Lang D, Janss AJ, Rorke LB, Philips PC, Shalaby T and Grotzer MA: Loss of Caspase-8 protein expression correlates with unfavorable survival outcome in childhood medulloblastoma. Clin Cancer Res 9: 6401-6409, 2003.

36. Gonzalez-Gomez P, Bello MJ, Inda MM, Alonso ME, Arjona D, Amiñoso C, Lopez-Marin I, de Campos JM, Sarasa JL, Castresana JS and Rey JA: Deletion and aberrant CpG island methylation of Caspase 8 gene in medulloblastoma. Oncol Rep 12: 663-666, 2004. 